\title{
Lifelong Learning Tendencies of Prospective Teachers Receiving Pedagogical Formation Education
}

\author{
Muamber Yılmaz \\ Department of Basic Education, Faculty of Education, Bartın University, Bartin, Turkey
}

Copyright $\mathrm{C} 2018$ by authors, all rights reserved. Authors agree that this article remains permanently open access under the terms of the Creative Commons Attribution License 4.0 International License

\begin{abstract}
Lifelong learning tendencies of prospective teachers attending pedagogical formation certificate program were evaluated in this study. While prospective teachers receiving pedagogical formation at Bartın University and Mustafa Kemal University formed the population of the research, the sample consisted of 210 prospective teachers selected randomly from the population. Screening model was employed in the research. "Personal Information Form" and 1-6 Likert-type "Lifelong Learning Tendencies Scale" which consisted of 27 items and was developed by Diker-Coşkun [17] were applied as data collection tools. Reliability of the scale was tested, and Cronbach Alpha coefficient was found as 0.72 . Independent samples t-test, one-way ANOVA and Dunnett's T3 test were employed in the study. As a result of the data analysis, lifelong learning tendencies of the prospective teachers receiving pedagogical formation were generally high. Furthermore, a statistically significant difference was observed based on variables of marital status, age, universities being studied at, job status and level of income. On the other hand, lifelong learning tendencies of the prospective teachers receiving pedagogical formation education did not have statistically significant differences by gender, having child/children, department of graduation and work experience.
\end{abstract}

Keywords Lifelong Learning, Lifelong Learning Tendencies, Pedagogical Formation Education, Prospective Teachers

\section{Introduction}

Teachers have a crucial role in development and progress of a society. Teachers are expected to follow scientific improvements and to improve themselves. Learning is a lifelong process. Teachers tend to learn during their whole lives to fulfill the expectations of the society.

Lifelong learning can be described as a process which improves individuals' knowledge and skills they gained throughout their lives ([9]; [3]; [49]). In other words, lifelong learning can be described as people's learnings that they acquire intentionally and purposefully for helping their self-improvement and life quality (Overly, Mc-Quigg, Silvernail, and Coppedge, 1980; as cited by Dunlap, [21]). Lifelong learning contains all formal, non-formal and continuous purposeful learning activities carried out with the aim of improving knowledge, skills and abilities within the frame of personal, communal, social and occupational life [10]. A lifelong learner is an individual who plans, gauges his/her own learning, gathers knowledge in different disciplines and applies various learning strategies [37]. Lifelong learning removes variables such as age, place, time and socio-economic status, and it also provides equality of opportunity to the individuals [16]. Furthermore, lifelong learning covers developed education policies, implementation of these policies in schools, adult education and lifelong formal and non-formal education [42].

Living, learning and working styles are rapidly changing in the $21^{\text {st }}$ century. It is not possible for educational systems, which have the function of preparing individuals to the life, to be inalterable in such a setting where everything is changing. In this respect, teaching ways of reaching information is important rather than giving information directly in our age. In other words, learning to learn is more important than teaching [1]. That is why, skills and competences gained through lifelong learning programs are crucial for gaining occupational responsibility employees need to have and for having knowledge and skills necessary for them to carry out new tasks [4]. In learning society of the information age, lifelong learning refers to everlasting learning process at home, at work, at a café, etc. with the aim of complying with ever-changing conditions, contrary to the educational and instructional skills embedded in a certain period of life. On the other hand, lifelong learning can create new 
opportunities for individuals by validating basic skills [52]. The fact that scientific, technological and cultural changes have been occurring rapidly caused humans to be in need of continuous learning [18].

One of the institutions placing great importance to lifelong learning is the European Commission, which described key competences of lifelong learning in [11] as follows:

1. Communication in the mother tongue,

2. Communication in foreign languages,

3. Mathematical competence and basic competences in science and technology,

4. Digital competence,

5. Learning to learn,

6. Social and civic competences,

7. Sense of initiative and entrepreneurship,

8. Competence in cultural awareness and expression

When literature was searched the following studies were found:

Mourtos [43] investigated lifelong learning skills of university students. As a result of the study, he suggested that some courses assisting students need to be arranged in order to improve their lifelong learning skills. Brahmi [8] investigated lifelong learning skills of medical faculty students. In the study, students expressed that lifelong learning was an internal wonder, and having a role-model was important in all steps of education. Kirby, Knapper, Lamon, Egnatoff [36] developed a scale for gauging lifelong learning in their study. Hart [26] claimed in his research that university students' using instructional technologies and in-class instructional strategies were effective in developing their self-learning skills. Cresson and Dean [12] carried out a research on 154 adult educators in an adult education center. As a result of the study, it was found out that adult educators supported lifelong learning, and their levels of belief on this topic were high. Loads [41] held a research on 5 academicians working as student advisers about lifelong learning. In this study, academicians stated that students' lifelong learning skills were affected by institutional structure, academicians and social environment. Reio [50] investigated the relationship between levels of curiousness and social learning - work performance of the adults. A significant relationship was found between level of curiousness and work performance as a result of the study. On the other hand, Atacanl1 [5] investigated lifelong learning behaviors of Medical Faculty graduate students at Ankara University. The students' readiness to self-learning was found mediocre in the study. Furthermore, scale scores of the students who had computers with access to internet, who fulfilled this need at faculties and who had habit of doing sports regularly were higher than the others. Besides, learning choice evaluation scale scores of the students willing to do academic study in the future were higher than of the ones willing to work as specialist physician. In Kara and Kürüm's [28] research, perception of the students studying at Primary School Teaching department in Education Faculty of Anadolu University about lifelong learning was analyzed. It was concluded in the study that the students did not know concepts related to lifelong learning sufficiently. Gencel [25] also investigated perceptions of prospective teachers towards lifelong learning competences. 551 students studying at Faculty of Education in Çanakkale Onsekiz Mart University were included in the study. As a result of the study, it was suggested that the prospective teachers regarded themselves "adequate", they regarded themselves adequate at communication in native language at most and adequate at communication in foreign language and in social-civic competence at least. Furthermore, perception of female prospective teachers about lifelong learning competences was higher than of the males. Additionally, while perceptions of the students at the departments of English Language and Literature, German Language Teaching, Turkish Language Teaching and Computer Education-Instructional Technologies about lifelong learning competences were high, perceptions of the students at the departments of Art Education and Music Education were less than of the other students. Karakuş [29] analyzed lifelong learning competences of vocational college students. It was revealed in the study carried out with 231 students that lifelong learning competences of the students were on a good level, and there was no significant difference among the departments. Oral and Yazar [45] studied lifelong learning perceptions of the prospective teachers in their research. They stated as a conclusion of their study that the prospective teachers' perceptions about lifelong learning did not differ by gender and departments. Özçiftçi [46] and Yıldırım [57] found in their research that lifelong learning tendencies of the class teachers were at a high level. It was also revealed that a significant difference was found in favor of boys, and no significant difference was observed by the variables of age, seniority and place of work.

In our age, individuals' developing lifelong learning tendencies has become more important in parallel with social changes and developments. Accordingly, even the most developed countries have plunged into a quest to develop their educational systems steadily and to increase educational quality. As teachers have a vital role in individuals' having lifelong learning tendency, individuals receiving pedagogical formation knowledge and skills also need to be responsible for lifelong learning.

When literature related to lifelong learning was investigated, most of the studies were about lifelong learning tendencies of university students ([44]; [29]; [18]) or teachers ([33]; [32]; [54]; [2]). Therefore, determining tendencies of the students receiving pedagogical formation regarding lifelong learning was believed to contribute to the field. 


\subsection{Aim of the Study}

In this study, lifelong learning tendencies of the prospective teachers were analyzed in relation to some variables (gender, marital status, having child/children, age, university being studied, department having been graduated, job status, level of income and work experience). The following questions were answered in order to achieve this aim of the study:

1. What are the lifelong learning tendencies of prospective teachers receiving pedagogical formation education?

2. Do their lifelong learning tendencies differ according to

a) gender

b) marital status

c) whether they have children

d) age

e) the universities which prospective teachers graduated from

f) the departments they graduated from

g) job status

h) level of income

i) work experience

3. At what level are lifelong learning tendencies of the prospective teachers receiving pedagogical formation education?

\section{Methodology}

\subsection{Research Model}

Survey model was employed in the study. Survey model aims to describe a situation existing in the past or being active currently as it is [30]. This model was selected since it aims to describe an existing situation as it is.

\subsection{Population and Sample}

While the prospective teachers receiving pedagogical formation education both at Bartın University and at Mustafa Kemal University in 2016-2017 academic year comprised population of the study, 210 prospective teachers randomly selected from this group formed the sample of the research. All of the prospective teachers in the sample had graduated from a bachelor's degree program. They applied to the universities for pedagogical formation education to be able to become teachers in the following years. Some of them had jobs while the others did not. On the other hand, some of them were married.

\subsection{Data Collection Tools}

"Personal Information Form" developed by the author and "Lifelong Learning Tendencies Scale" with 27 items developed by Diker-Coşkun [17] were used for data collection. This scale was preferred since its validity and reliability study had been carried out. Turkish version of this scale was used since the participants of the study were Turkish.

The scale consisted of four sub-scales which were motivation, persistence, a deficiency of arranging learning and a deficiency of wonder. However, the sub-scales were not applied in the current study. The scale was 6-likert type with "complying a lot", "complying partially", "complying slightly", "not complying slightly", "not complying partially" and "not complying at all". When 1 was considered as the start point, the value 3,5 was supposed as midpoint of "complying slightly" and "not complying slightly". Accordingly, minimum score to be received from the lifelong learning tendencies scale was $27(27 \times 1)$ while median score was $94,5(27 \times 3,5)$ and maximum score was $162(27 x 6)$.

Cronbach's Alpha internal consistency coefficient of the lifelong learning tendencies scale with 27 items was found as .89 in the research carried out by Diker-Coşkun [17]. In the study, reliability of the scale was re-tested, and Cronbach's alpha coefficient was calculated as 0.72 . The scale was used to analyze general lifelong learning tendencies of the prospective teachers.

\subsection{Data Analysis}

SPSS (Statistical Package for Social Science) program was used in data analysis. Kolmogorov-Smirnov and Shapiro-Wilk tests were applied in order to determine whether the data showed normal distribution or not. As $p$ value was higher than .05 according to the results of these tests, the data were regarded to be in normal distribution. Furthermore, the fact that the data showed normal distribution was confirmed with Levene's test. Independent samples t-test and one-way ANOVA were employed for data analysis. Additionally, Dunnett's T3 test was applied to determine difference between the groups as a result of one-way analysis.

\section{Results}

The data obtained from the study were shown in tables as follows.

Table 1. Independent Samples t-test Results of the Scores Received from Lifelong Learning Tendencies Scale by the Prospective Teachers Receiving Pedagogical Formation Education by Gender

\begin{tabular}{ccccccc}
\hline Gender & $\mathbf{N}$ & $\overline{\mathrm{X}}$ & $\mathbf{s d}$ & $\mathbf{d f}$ & $\mathbf{t}$ & $\mathbf{p}$ \\
\hline Male & 83 & 125.87 & 16.442 & 208 & -1.699 & .091 \\
Female & 127 & 129.54 & 14.496 & & & \\
\hline
\end{tabular}

The data in Table 1 revealed that there was no significant difference between the scores received from lifelong learning tendencies scale by the prospective 
teachers receiving pedagogical formation education and gender variable $[\mathrm{t}(208)=-1.699 ; \mathrm{p}>.05]$.

Table 2. Independent Samples t-test Results of the Scores Received from Lifelong Learning Tendencies Scale by the Prospective Teachers Receiving Pedagogical Formation Education by Marital Status

\begin{tabular}{ccccccc}
\hline Marital Status & $\mathbf{N}$ & $\overline{\mathrm{X}}$ & $\mathbf{s d}$ & $\mathbf{d f}$ & $\mathbf{t}$ & $\mathbf{p}$ \\
\hline Married & 61 & 131.31 & 11.591 & & & \\
Single & 149 & 126.77 & 16.514 & 208 & 2.264 & .025 \\
\hline
\end{tabular}

According to the results given in Table 2, there was significant difference between the scores received from lifelong learning tendencies scale by the prospective teachers receiving pedagogical formation education and the variable of marital status $[\mathrm{t}(208)=2.264 ; \mathrm{p}<.05]$. This significant difference was in favor of the married prospective teachers.

Table 3. Independent Samples t-test Results of the Scores Received from Lifelong Learning Tendencies Scale by the Prospective Teachers Receiving Pedagogical Formation Education by the Variable of Having Child/Children

\begin{tabular}{ccccccc}
\hline $\begin{array}{c}\text { Having } \\
\text { Child/Children }\end{array}$ & N & $\overline{\mathrm{X}}$ & sd & df & $\mathbf{t}$ & $\mathbf{p}$ \\
\hline Yes & 49 & 130.14 & 13.506 & & & \\
No & 161 & 127.46 & 15.869 & 208 & -1.071 & .285 \\
\hline
\end{tabular}

As it can be seen in Table 3, there was no significant difference between the scores received from lifelong learning tendencies scale by the prospective teachers receiving pedagogical formation education and the variable of having child/children [t(208) $=-1.071 ; \mathrm{p}>.05]$.

Table 4. One-Way ANOVA Results of the Scores Received from Lifelong Learning Tendencies Scale by the Prospective Teachers Receiving Pedagogical Formation Education by Age Variable

\begin{tabular}{cccccc}
\hline $\begin{array}{c}\text { Source of } \\
\text { Variance }\end{array}$ & $\begin{array}{c}\text { Sum of } \\
\text { Squares }\end{array}$ & df & $\begin{array}{c}\text { Sum of } \\
\text { Squares }\end{array}$ & F & p \\
\hline Inter-groups & 4289.252 & 4 & 1072.313 & & \\
Within-Groups & 45029.205 & 205 & 219.655 & 4.882 & .001 \\
Total & 493118.457 & 209 & & & \\
\hline
\end{tabular}

According to Table 4 , the scores received from lifelong learning tendencies scale by the prospective teachers receiving pedagogical formation education showed significant difference by age variable $[\mathrm{F}(4,205)=4.882$; $\mathrm{p}<.05]$. Dunnett's T3 test was employed to find out between which groups this difference was. According to Dunnett's T3 test results, there was significant difference between the prospective teachers who were 36 years old and over and the ones that were $20-27$ years old. The difference was in favor of the ones that were 36 years old and over.

It can be concluded from Table 5 that there was significant difference between the scores received from lifelong learning tendencies scale by the prospective teachers receiving pedagogical formation education and the variable of universities being studied $[\mathrm{t}(208)=2.597$; $\mathrm{p}<.05]$. This difference was in favor of the prospective teachers studying at Bartın University.
Table 5. Independent Samples T-test Results of the Scores Received from Lifelong Learning Tendencies Scale by the Prospective Teachers Receiving Pedagogical Formation Education by the Variable of Universities They Studied

\begin{tabular}{ccccccc}
\hline $\begin{array}{c}\text { Universities } \\
\text { They Studied }\end{array}$ & $\mathbf{N}$ & $\overline{\mathrm{X}}$ & $\mathbf{\text { sd }}$ & $\mathbf{d f}$ & $\mathbf{t}$ & $\mathbf{p}$ \\
\hline $\begin{array}{c}\text { Bartın } \\
\text { University } \\
\text { Mustafa Kemal } \\
\text { University }\end{array}$ & 115 & 130.59 & 13.980 & & & \\
\hline
\end{tabular}

Table 6. One-Way ANOVA Results of the Scores Received from Lifelong Learning Tendencies Scale by the Prospective Teachers Receiving Pedagogical Formation Education by the Variable of Departments They Graduated From

\begin{tabular}{cccccc}
\hline $\begin{array}{c}\text { Source of } \\
\text { Variance }\end{array}$ & $\begin{array}{c}\text { Sum of } \\
\text { Squares }\end{array}$ & df & $\begin{array}{c}\text { Sum of } \\
\text { Squares }\end{array}$ & F & p \\
\hline Inter-Groups & 464.669 & 2 & 232.335 & & \\
Within-Groups & 48853.788 & 207 & 236.009 & & .375 \\
Total & 49318.454 & 209 & & & \\
\hline
\end{tabular}

The data in Table 6 revealed that there was no significant difference between the scores received from lifelong learning tendencies scale by the prospective teachers receiving pedagogical formation education and the variable of departments graduated $[\mathrm{F}(3,206)=.984$; $\mathrm{p}>.05]$.

Table 7. Independent Samples T-test Results of the Scores Received from Lifelong Learning Tendencies Scale by the Prospective Teachers Receiving Pedagogical Formation Education by the Variable of Job Status

\begin{tabular}{ccccccc}
\hline Job Status & $\mathbf{N}$ & $\overline{\mathrm{X}}$ & $\mathbf{s d}$ & $\mathbf{d f}$ & $\mathbf{t}$ & $\mathbf{p}$ \\
\hline Working & 102 & 131.04 & 14.965 & & & \\
Not Working & 108 & 125.30 & 15.276 & 208 & 2.750 & .006 \\
\hline
\end{tabular}

As it can be understood from Table 7, there was significant difference between the scores received from lifelong learning tendencies scale by the prospective teachers receiving pedagogical formation education and the variable of job status $[\mathrm{t}(208)=2.750 ; \mathrm{p}<.05]$. This difference was in favor of the ones working.

Table 8. One-Way ANOVA Results of the Scores Received from Lifelong Learning Tendencies Scale by the Prospective Teachers Receiving Pedagogical Formation Education by Their Levels of Income

\begin{tabular}{cccccc}
\hline $\begin{array}{c}\text { Source of } \\
\text { Variance }\end{array}$ & $\begin{array}{c}\text { Sum of } \\
\text { Squares }\end{array}$ & df & $\begin{array}{c}\text { Sum of } \\
\text { Squares }\end{array}$ & F & p \\
\hline Inter-Groups & 2491.161 & 4 & 622.790 & & \\
Within-Groups & 46827.296 & 205 & 228.426 & & .726 \\
Total & 49318.457 & 209 & & & \\
\hline
\end{tabular}

According to Table 8 , there was significant difference between the scores received from lifelong learning tendencies scale by the prospective teachers receiving pedagogical formation education and their levels of income $[F(4,205)=2.726 ; p<.05]$. Dunnett's T3 Test was employed in order to determine between which groups the difference was. Based on the test results, there was significant difference between the prospective teachers whose levels of income were 2001-3000 TL and the ones who had no level of income. Moreover, this difference 
was in favor of those whose levels of income were 2001-3000 TL.

Table 9. One-Way ANOVA Results of the Scores Received from Lifelong Learning Tendencies Scale by the Prospective Teachers Receiving Pedagogical Formation Education by Their Work Experiences

\begin{tabular}{cccccc}
\hline $\begin{array}{c}\text { Source of } \\
\text { Variance }\end{array}$ & $\begin{array}{c}\text { Sum of } \\
\text { Squares }\end{array}$ & df & $\begin{array}{c}\text { Sum of } \\
\text { Squares }\end{array}$ & F & p \\
\hline Inter-Groups & 1254.022 & 3 & 418.007 & & \\
Within-Groups & 48064.435 & 206 & 233.323 & 1.792 & .150 \\
Total & 49318.457 & 209 & & & \\
\hline
\end{tabular}

According to Table 9, there was no significant difference between the scores received from lifelong learning tendencies scale by the prospective teachers receiving pedagogical formation education and their work experiences $[\mathrm{F}(3,206)=1.792 ; \mathrm{p}>.05]$.

Table 10. Overall Lifelong Learning Tendencies of the Prospective Teachers Receiving Pedagogical Formation Education

\begin{tabular}{ccccccc}
\hline & N & $\begin{array}{c}\text { Min. } \\
\text { Score }\end{array}$ & $\begin{array}{c}\text { Median } \\
\text { Score }\end{array}$ & $\begin{array}{c}\text { Max. } \\
\text { Score }\end{array}$ & $\overline{\mathrm{X}}$ & ss \\
\hline $\begin{array}{c}\text { Whole } \\
\text { Scale }\end{array}$ & 210 & 27 & 94.5 & 162 & 128.09 & 15.361 \\
\hline
\end{tabular}

As a result of Table 10, the minimum score to be received from the lifelong learning tendencies scale by the prospective teachers was 27 and the maximum score was 162. It was found out that mean score that the students received from the scale was (128.09) higher than median score of the scale (94.5). In this case, it is possible to claim that lifelong learning tendencies of the prospective teachers were high.

\section{Discussion and Conclusions}

When the scores received from the lifelong learning tendencies scale by the married and single prospective teachers were compared, it was revealed that there was a significant difference in favor of the married ones. There was a significant difference between the prospective teachers that were 36 or over and the ones who were 20-27. Moreover, this difference was in favor of the ones that were 36 or older. A significant difference was observed between universities being studied (Mustafa Kemal University and Bartın University). This difference was in favor of the prospective teachers studying at Bartın University. On the other hand, there was a significant difference between the scores received from the lifelong learning tendencies scale by the prospective teachers receiving pedagogical formation education and their job status, and this difference was in favor of the ones who had a job. There was also a significant difference between the prospective teachers who had income between 2001-3000 TL and the ones who had no income. The difference was in favor of the prospective teachers who had income between 2001-3000 TL.

The results obtained had some similarities and differences with the previous studies. These similarities and differences are important since it gives the chance to assure the validity and contribution of the current study. In the research, lifelong learning tendencies of the prospective teachers receiving pedagogical formation education did not show significant difference by their genders. This finding shows some similarities and differences with the previous studies. Yaman [55], Oral and Yazar [45], Şahin, Akbaşlı and Yanpar Yelken [53], Arcagök and Şahin [2], Kozikoğlu [39], Savuran [51], Tunca, Şahin and Aydın [54], Dündar [22] suggested in their studies that gender factor did not affect lifelong learning tendencies of the prospective teachers. Additionally, Yıldırım [57] Ayaz [6], Yaman and Yazar [56] stated in their studies carried out with teachers that gender factor was not effective on lifelong learning tendencies of the teachers. Doğan and Kavtelek [19] found out that gender was not effective on lifelong learning tendencies of the institutional executives. On the contrary, Demirel and Akkokunlu [14], Karakuş [29], Gencel [25], Kılıç and Tuncel [33], Diker-Coşkun and Demirel [18], Demiralay [15], Erdoğan [24], stated in their studies that lifelong learning tendencies of the prospective teachers changed by their genders. Furthermore, effect of gender variable on lifelong learning tendencies was confirmed by Kılınç and Yenen [34] who carried out the research with trainees in public training centers, by Diker Coşkun [17] who held the study with university students, by Konokman and Yanpar Yelken [38] who carried out their research with academic staff. Deakin Crick, Broadfoot and Claxton [13] determined in their research about lifelong learning that the girls' scores related to learning timidity, creativity and learning relations were higher than the boys'; however, the boys' scores related to strategic awareness and critical curiousness were higher.

In the research carried out, lifelong learning tendencies of the prospective teachers did not differ by the variable of having child / children. It was found by Özkorkmaz [47] whose sample was public training center executives and by Duman [20] whose sample was master's students that there was no significant difference between lifelong learning tendency and marital status. These results are parallel to our findings.

As a result of the research, lifelong learning tendencies of the prospective teachers receiving pedagogical formation did not show a difference by departments they graduated. This finding is similar with the previous studies. Oral and Yazar [45], Karakuş [29] also claimed that lifelong learning tendencies of the prospective teachers did not change based on departments being studied at. On the other hand, Arcagök and Şahin [2], Tunca, Şahin and Aydın [54], Diker Coşkun and Demirel [18], Gencel [25], İzci and Koç [27] and Savuran [51], Şahin, Akbaşlı and Yanpar Yelken [53] concluded that lifelong learning tendencies of the prospective teachers showed a difference by departments being studied at. The same finding was obtained by Ekinci [23] who implemented the research on university students. 
Another finding of the study was the fact that lifelong learning tendencies of the prospective teachers receiving pedagogical formation were not different by their work experiences. Özçiftçi [46] also revealed that there was no statistically significant difference between lifelong learning tendencies of the class teachers and their seniorities. Finding obtained in our study and Özçiftçi's conclusion show similarity. On the contrary, Yaman [55], Arcagök and Şahin [2], Yıldırım [57], Kılıç and Tuncel [33] suggested that there was a significant difference between lifelong learning tendencies of the teachers and their seniorities. Additionally, Bahat [7] claimed that there was a significant difference between lifelong learning tendencies of public training centers directors and their seniorities. These findings were different from the ones obtained from our study.

It was found in this research that there was a significant difference between lifelong learning tendencies of the prospective teachers receiving pedagogical formation and the variable of marital status, and this difference was in favor of the married ones. This finding is different from the previous studies. Duman [20] concluded in his research that lifelong learning tendencies of the masters' students and their marital status were not statistically different.

Another finding of the research was that there was a significant difference between lifelong learning tendencies of the prospective teachers receiving pedagogical formation education and age variable, and this difference was in favor of the older ones. This finding shows similarities with the previous studies. Kılıç [32] claimed in his study that there was a significant difference between lifelong learning tendencies of the prospective teachers and age variable, and this difference was in favor of the older ones. In addition to this, Doğan and Kavtelek [19], determined in their study that there was a significant difference between lifelong learning tendencies of the institutional executives and age variable. However, Kara and Kürüm [28], Özçiftçi [46], and Duman [20] stated in their studies that there was no significant difference between lifelong learning tendencies of the prospective teachers, the class teachers and master's students respectively and age variable. Similarly, Kıran [35] suggested in his study that age variable did not affect lifelong learning tendency. There is difference between our findings and those studies.

Lifelong learning tendencies of the prospective teachers receiving pedagogical formation education showed a significant difference by universities being studied. Köksal and Göçmen [40] revealed that there was a significant difference between lifelong learning tendencies of the prospective teachers studying at Van Yüzüncü Yıl University and Pamukkale University. Moreover, Diker Coşkun [17] found out that a significant difference was observed between lifelong learning tendencies of the university students studying at Marmara University and
Yeditepe University. Özmenteş [48] claimed that lifelong learning tendencies of the university students differed by universities they studied at. Kozikoğlu [39] also highlighted that type of schools was effective on lifelong learning. These findings and findings obtained from the current study show similarities.

In the current study, lifelong learning tendencies of the prospective teachers receiving pedagogical formation education created difference based on their job status, and the difference was in favor of the ones who had a job. This finding is similar to Kıran's [35] finding he revealed in his research. Kiran [35] expressed that level of income was effective on lifelong learning tendencies of the trainees in public training centers.

Another finding obtained from the study that there was a significant difference between lifelong learning tendencies and their levels of income, and this difference was in favor of the ones whose levels of income were high. This conclusion is similar to and different from the previous studies in some ways. Diker Coşkun [17] revealed that there was a significant difference between lifelong learning tendencies of the university students and their levels of income. It was found in that study that lifelong learning tendencies of the university students whose levels of income were high were low. However, in our study was it concluded that lifelong learning tendencies of the prospective teachers receiving pedagogical formation education were high. On the other hand, Dündar [22], Kılıç [32] claimed that there was no significant difference between lifelong learning tendencies of the prospective teachers and their levels of income

Finally, lifelong learning tendencies of the prospective teachers were found high in the current study. This conclusion shows some similarities and differences with the previous studies. While Kılıç [32], Tunca, Şahin and Aydın [54], Oral and Yazar [45], Gencel [25] suggested that lifelong learning tendencies of the prospective teachers were high, Diker Coşkun [17] claimed that lifelong learning tendencies of the university students were low.

As a conclusion, no statistically significant difference was observed in lifelong learning tendencies of the prospective teachers by gender, having child/children, department of graduation and work experience. On the other hand, there was a statistically significant difference by marital status, age, university being studied at, job status and levels of income. Furthermore, lifelong learning tendencies of the prospective teachers receiving pedagogical formation education were high in general. However, awareness about lifelong learning tendencies of the prospective teachers receiving pedagogical formation education should be created. As the current study was limited to the prospective teachers receiving pedagogical formation education at Bartın University and Mustafa Kemal University, further studies with different sample can be carried out in the future. 


\section{REFERENCES}

[1] Aksoy, M. (2013). Kavram olarak hayat boyu öğrenme ve hayat boyu öğrenmenin Avrupa Birliği serüveni. Bilig: Türk Dünyası Sosyal Bilimler Dergisi, 64, 23-48.

[2] Arcagök, S. and Şahin, Ç. (2014). Öğretmenlerin yaşam boyu öğrenme yeterlilikleri düzeyinin çeşitli değişkenler açısından incelenmesi. Adlyaman Üniversitesi Sosyal Bilimler Enstitüsü Dergisi, 7(16), 394- 417.

[3] Aspin, D. N. and Chapman, J. D. (2000). Lifelong learning: concepts and conceptions. International Journal of Lifelong Education, 19(1), 2-19.

[4] Aspin, D. and Chapman, J. D. (2001). Lifelong learning: concepts, theories and values. Paper Presented at SCUTREA, 31st Annual Conference, 3-5 July 2001, University of East London.

[5] Atacanl1, M. F. (2007). Ankara üniversitesi tıp fakültesi öğrencilerinin öğrenme tercihi değerlendirme ölçeğ aracılığıyla yaşam boyu ögrenme davranışının yıllara göre değişiminin araştırılması. (Yayınlanmamış Yüksek Lisans Tezi). Ankara Üniversitesi, Tıp Eğitimi ve Bilişimi Anabilim Dal1, Ankara.

[6] Ayaz, C. (2016). Öğretmenlerin yaşam boyu öğrenme eğilimlerinin bazı değişkenler açısından incelenmesi (Mardin ili örneği). (Yayınlanmamış Yüksek Lisans Tezi). Bartın Üniversitesi Eğitim Bilimleri Enstitüsü, Bartın.

[7] Bahat, İ. (2013). Halk eğitimi merkezi yöneticilerinin hayat boyu ögrenme algısı. (Yayımlanmamış Yüksek Lisans Tezi). Marmara Üniversitesi Eğitim Bilimleri Enstitüsü, İstanbul.

[8] Brahmi, A. F. (2007). Medical students' perceptions of lifelong learning at Indiana unversity school of medicine. (Unpublished Doctoral Dissertation). Indiana University, School of Library and Information Science, USA.

[9] Candy, P. C. (1994). Lifelong learning and information literacy. Report for US. National Commission on Libraries and Information Science and National Forum on Information Literacy.

[10] Commission of the European Communities (2006). Recommendation of the European parliament and of the council on key competences for lifelong learning. http://eur-lex.europa.eu/legalcontent/EN/TXT/?uri=celex:3 2006H0962 Date of access: 20.04.2016.

[11] Commission of the European Communities (2007). Directorate-General for Education and Culture. Key Competences for Lifelong Learning European Reference Framework, Brussels, Belgium, EC Lifelong Learning Programme.

http://bookshop.europa.eu/en/key-competences-for-lifelon g-learningpbNC7807312/?CatalogCategoryID $=\mathrm{u} 9$ oKABstI EwAAAEjboUY4e5K Date of access: 20.04.2016.

[12] Cresson C. J. and G. J. Dean. (2000). Lifelong learning and adult educators' beliefs: implications for theory and practice. PAACE Journal of Lifelong Learning, 9, 87- 98.

[13] Deakin Crick R., Broadfoot P. and Claxton G. (2004). Developing an effective lifelong learning inventory: The
ELLI project. Assessment in Education, 11(3), 247-272.

[14] Demirel, M. and Akkoyunlu, B. (2010). Öğretmen adaylarının yaşam boyu öğrenme eğilimleri ve bilgi okuryazarlığı öz yeterlilik algıları. 10 th. International Educational Tecnollogy Conference, (26-28 Nisan, 2010), Boğaziçi Üniversitesi, Istanbul, Proceeding Book, Volume 2, 1126-1133.

[15] Demiralay, R. (2008). Öğretmen adaylarının bilgi ve iletişim teknolojilerini kullanımları açısından bilgi okuryazarlı̆̆ öz-yeterlik algılarının değerlendirilmesi. (Yayımlanmamış Yüksek Lisans Tezi). Gazi Üniversitesi, Eğitim Bilimleri Enstitüsü, Ankara.

[16] Dineveski, D., and Dineveski, I. V. (2004). The concepts of universty lifelong learning provision in Europe. Transition Studies Review, 13 (3), 227-235

[17] Diker Coşkun, Y. (2009). Üniversite öğrencilerinin yaşam boyu ögrenme ĕgilimlerinin bazı değişkenler açısından incelenmesi. (Yayınlanmamış Doktora Tezi). Hacettepe Üniversitesi, Sosyal Bilimler Enstitüsü, Ankara.

[18] Diker Coşkun, Y. and Demirel, M. (2012). Üniversite öğrencilerinin yaşam boyu öğrenme eğilimleri. Hacettepe Üniversitesi Ĕ̈itim Fakültesi Dergisi, 42(42), 108-120.

[19] Doğan, S. and Kavtelek, C. (2015). Hayat boyu öğrenme kurum yöneticilerinin hayat boyu öğrenmeye ilişkin algıları. Abant İzet Baysal Üniversitesi Eğitim Fakültesi Dergisi, 15(1), 82-104.

[20] Duman, A. (2004). Ankara üniversitesi eğitim bilimleri enstitüsü yüksek lisans programlarına kayıtlı olan öğrencilerin güdüsel yönelimleri. Eğitim Bilim Toplum Dergisi, 2(6), 34-45.

[21] Dunlap, J. C. (2005). Changes in students' use of lifelong learning skill during a problem-based learning project. Performance Improvement Quarterly, 18(1), 5-33.

[22] Dündar, H. (2016). Sınıf öğretmeni adaylarının yaşam boyu öğrenme eğilimlerinin incelenmesi. (Yayınlanmamış Yüksek Lisans Tezi). Atatürk Üniversitesi Eğitim Bilimleri Enstitüsü, Erzurum.

[23] Ekinci, N. (2008). Üniversite öğrencilerinin ögrrenme yaklaşımlarının belirlenmesi ve öğretme-öğrenme süreci değişkenleri ile ilişskileri. (Yayınlanmamış Doktora Tezi). Hacettepe Üniversitesi. Sosyal Bilimler Enstitüsü, Ankara.

[24] Erdoğan, D. G. (2014). Öğretmen adaylarının yaşam boyu ögrenme eğilimlerine etki eden faktörler. (Yayımlanmamış Doktora Tezi). Abant İzzet Baysal Üniversitesi, Eğitim Bilimleri Enstitüsü, Bolu.

[25] Gencel, İ. E. (2013). Öğretmen adaylarının yaşam boyu öğrenme yeterliklerine yönelik algıları. Eğitim ve Bilim Dergisi, 38(170), 237-252.

[26] Hart, R. (2006). Using e-learning to help students develop lifelong learning skills. (Unpublished Doctoral Dissertation). Royal Roads University.

[27] İzci, E. and Koç, S. (2012). Öğretmen adaylarının yaşam boyu öğrenmeye ilişkin görüşlerinin değerlendirilmesi. Adıyaman Üniversitesi Sosyal Bilimler Enstitüsü Dergisi, 5(9), 101-114.

[28] Kara, D. and Kürüm, D. (2007). Sinıf öğretmeni 
adaylarının yaşam boyu öğrenme kavramına yükledikleri anlam (Anadolu üniversitesi eğitim fakültesi örneği). 16. Ulusal Eğitim Bilimleri Kongresi, 5-7 Eylül, Tokat.

[29] Karakuş, C. (2013). Meslek Yüksek Okulu öğrencilerinin yaşam boyu öğrenme yeterlikleri. Ĕgitim ve Öğretim Araştırmaları Dergisi, 2(3), 26-35.

[30] Karasar, N. (2009). Bilimsel araştırma yöntemleri. Ankara: Nobel Yayıncilik.

[31] K1lıç, Ç. (2014). Öğretmen adaylarının yaşam boyu öğrenmeye yönelik alg1ları. Ĕgitim ve Öğretim Araştırmaları Dergisi, 3(4), 79-87.

[32] K1lıç, H. (2015). İlköğretim branş öğretmenlerinin bireysel yenilikçilik düzeyleri ve yaşam boyu ögrenme eğilimleri (Denizli ili örneği). (Yayınlanmamış Yüksek Lisans Tezi). Pamukkale Üniversitesi Eğitim Bilimleri Enstitüsü, Denizli.

[33] K1lıç, H. and Tuncel, A. Z. (2014). İlköğretim branş ögrretmenlerinin bireysel yenilikçilik düzeyleri ve yaşam boyu öğrenme eğilimleri. Uluslarası Eğitim Programları ve Öğretim Çalışmaları Dergisi, 4(7), 25-37.

[34] Kilınç, H. H. and Yenen, E. T. (2015). Halk eğitim merkezi kursiyerlerinin yaşam boyu öğrenme eğilimleri. The Journal of Academic Social Science Studies. 35, 187-198.

[35] Kıran, İ. (2008). Yaşam boyu eğitimin sağlanmasında halk eğitimi merkezlerinin değerlendirilmesi: Yüreğir halk ĕgitimi merkezi örneği. (Yayınlanmamış Yüksek Lisans Tezi). Gazi Üniversitesi Eğitim Bilimleri Enstitüsü, Ankara.

[36] Kirby, J. R., Knapper, C., Lamon, P. and Egnatoff, W. J. (2010). Development of a scale to measure lifelong learning. International Jorunal of Lifelong Education, 29(3), 291-302.

[37] Knapper, C. K. and Cropley, A. J. (2000). Lifelong Learning in Higher Educaiton. (3rd ed.) London: Kogan Page.

[38] Konokman, Y. G. and Yanpar Yelken, T. (2014). Eğitim fakültesi öğretim elemanlarının yaşam boyu öğrenme yeterliklerine ilişkin algıları. Hacettepe Üniversitesi Eğitim Fakültesi Dergisi, 29, 267-281.

[39] Kozikoğlu, İ. (2014). Üniversite ve meslek yüksekokulu öğrencilerinin yaşam boyu öğrenme yeterliklerinin incelenmesi. Journal of Instructional Technologies \& Teacher Education, 3(3), 29-43.

[40] Köksal, N. and Göçmen, S. (2014). Öğretmen adaylarının mesleki gelişimlerini destekleyici üniversite olanakları. Pamukkale Üniversitesi Ĕ̈itim Fakültesi Dergisi, Sayı 35 (Ocak 2014/I), 85-98.

[41] Loads, D. (2007). Effective learning advisers' perceptions of their role in supporting lifelong learning. Teaching in Higher Education, 12(2), 235-245.

[42] Morgan-Klein, B. and Osborne, M. (2007). The Concepts and Practices of Lifelong Learning. Oxon: Routledge.

[43] Mourtos, N. J. (2003). Defining, teaching and assessing lifelong learning skills. [http://citeseerx.ist.psu.edu/viewdoc/download?doi=10.1.1. $501.8223 \&$ rep $=$ rep1\&type $=$ pdf] Date of access: 15.11.2015.

[44] Oral, B. and Yazar, T. (2013). International perspectives on new aspectes of learning in teacher education. IPALTE. 2-4 October 2013. Dicle Üniversitesi, Diyarbakır.

[45] Oral, B. and Yazar, T. (2015). Öğretmen adaylarının yaşam boyu öğrenmeye ilişkin algılarının çeşitili değişkenlere göre incelenmesi. Elektronik Sosyal Bilimler Dergisi, 14(52), 1-11.

[46] Özçiftçi, M. (2014). Sinıf öğretmenlerinin yaşam boyu ögrenme eğilimleri ile eğitim teknolojisi standartlarına yönelik özyeterliklerinin ilişkisi. (Yayımlanmamış Yüksek Lisans tezi). Amasya Üniversitesi, Sosyal Bilimler Enstitüsü, Amasya.

[47] Özkorkmaz, M. A. (2016). Türkiye'de halk eğitim merkezi müdürlerinin yașam boyu öğrenme yeterlik algıları. (Yayınlanmamış Yüksek Lisans Tezi). Sakarya Üniversitesi Eğitim Bilimleri Enstitüsü, Sakarya.

[48] Özmenteş, S. (2007). Çalgı çalışma sürecinde öz düzenlemeli ögrenme ile duyuşsal özellikler ve performans düzeyi ilişkileri. (Yayınlanmamış Doktora Tezi). Dokuz Eylül Üniversitesi Eğitim Bilimleri Enstitüsü, İzmir.

[49] Rausch, A. S. (2003). A case of lifelong in Japan: objectives curriculum, accountability and visibility. International of Lifelong Education, 22(5), 518-532.

[50] Reio, T. G. (1997). Effects of curiosity on socialization-related learning and job performance in adults. (Unpublished Doctoral Dissertation). Virginia Polytechnic Institute and State University, USA.

[51] Savuran, Y. (2014). Ingilizce öğretmen adaylarının mentorlarına klyasla yaşam boyu öğrenme becerileri. (Yayınlanmamış Yüksek Lisans Tezi). Hacettepe Üniversitesi Eğitim Bilimleri Enstitüsü, Ankara.

[52] Soran, H., Akkoyunlu, B. and Kavak, Y (2006). Yaşam boyu ögrrenme becerileri ve eğiticilerin eğitimi programı: Hacettepe Üniversitesi örneği. H.Ü. Ĕ̆itim Fakültesi Dergisi, 30, 201-210.

[53] Şahin, M., Akbaşlı, S. and Yanpar Yelken T. (2010). Key competences for lifelong learnıng: the case of prospective teachers. Educational Research and Review, 5(10), 545-556.

[54] Tunca, N., Şahin, S. A. and Aydın, Ö. (2015). Öğretmen adaylarının yaşam boyu öğrenme eğilimleri. Mersin Üniversitesi Ĕgitim Fakültesi Dergisi, 11(2), 432-446.

[55] Yaman, F. (2014). Öğretmenlerin yașam boyu öğrenme ĕgilimlerinin incelenmesi (Diyarbakır il örneği). (Yayınlanmamış Yüksek Lisans Tezi). Dicle Üniversitesi Eğitim Bilimleri Enstitüsü, Diyarbakır.

[56] Yaman, F. and Yazar, T. (2015). Öğretmenlerin yaşam boyu öğrenme eğilimlerinin incelenmesi (Diyarbakır ili örneği). Kastamonu Eğitim Dergisi, 23(4), 1553-1566.

[57] Yıldırım, Z. (2015). Sinıf öğretmenlerinin yaşam boyu ögrenmeye yönelik yeterlik algıları ve görüşleri. (Yayınlanmamış Yüksek Lisans Tezi). Çanakkale on Sekiz Mart Üniversitesi, Eğitim Bilimleri Enstitüsü, Çanakkale. 